\title{
Women leadership styles in the public sector in Kuwait: The perspective of their subordinates
}

\author{
Basil Alzougoola $^{\text {a }}$ Jarrah AlMansour $^{\mathrm{a}^{*}}$ and Mohammad AlAjmi ${ }^{\mathrm{a}}$
}

${ }^{a}$ Arab Open University, Kuwait

\begin{tabular}{|c|c|}
\hline C H R O N I C L E & A B S T RACT \\
\hline $\begin{array}{l}\text { Article history: } \\
\text { Received: June 20, } 2020 \\
\text { Received in revised format: } \\
\text { August } 302020 \\
\text { Accepted: September 18, } 2020 \\
\text { Available online: } \\
\text { September } 18,2020 \\
\text { Keywords: } \\
\text { Leadership } \\
\text { Women } \\
\text { Public Sector } \\
\text { Kuwait }\end{array}$ & $\begin{array}{l}\text { Little research has been devoted to focus on women's leadership styles in particular especially in } \\
\text { Kuwait. The aim of this study is therefore twofold: (i) to identify the different leadership styles of } \\
\text { women in the public sector in Kuwait, and (ii) to examine if the identified leadership styles of } \\
\text { women vary in terms of the demographic characteristics of their subordinates. A quantitative study } \\
\text { (questionnaire with } 263 \text { employees) is conducted in order to achieve the study objectives. The re- } \\
\text { sults of the study show that women in public sector in Kuwait frequently displayed various leader- } \\
\text { ship styles as perceived by their followers such as inspirational motivation, idealized influence } \\
\text { (attribute) styles. Some other styles were displayed fairly often such as management by exception } \\
\text { (active), idealized influence (behavior). Moreover, the dominated leadership styles that displayed } \\
\text { frequently by women was the transformational style. The study found that the transformational } \\
\text { leadership style of women varied in terms of the educational level and job title of their followers. } \\
\text { Several recommendations were suggested based on these findings that may improve the effective- } \\
\text { ness of women leadership in the public sector. }\end{array}$ \\
\hline
\end{tabular}

\section{Introduction}

Leadership is a complex phenomenon that touches on many other important organizational, social and personal processes. It depends on a process of influence, whereby people are inspired to work towards group goals, not through coercion, but through personal motivation" (Bolden, 2004). There has been a growth in the women holding senior and leading positions around the world. For example, Holmes (2014) found that $51 \%$ of senior management positions were held by women in China. This increasing rate can be seen in other countries as well e.g., Japan (7\%), United Arab Emirates (11\%), and Netherlands (11\%). Kuwait enhances the role of women and the importance of their presence in all sectors e.g. (political, social and economic life). "Kuwait allowed women to vote and seek public office for the first time in 2005 (Schmidt et al. 2014, p. 155). Kuwait ranks 81 with $6.7 \%$ women in ministerial positions and ranks 135 in terms of women in parliament with $4.6 \%$ women in lower or single house, far behind the global status (cited in Alzuabi, 2016). Kuwaiti women held numerous leadership positions such as national ambassadors and editors in chief of major newspapers. Women occupied $10.3 \%$ of leadership positions in the public sector in 2011. Also, woman's employment comprised 54.24\% of the overall workforce in the public sector (cited in Alzuabi, 2016). Al-Salem and Speece (2017) concluded that there seems to be general acceptance that women in Kuwait can be leaders in managerial positions, and little overt discrimination.

Much has been written about different leadership styles of managers (e.g. Alzougool et al., 2015; Yaseen, 2010; Rohmann \& Rowold, 2009, Sabri, 2007). However, little have been devoted to focus on women's leadership styles in particular especially in Kuwait. In this study; a leadership style is defined as "relatively stable patterns of behavior displayed by leaders" (Eagly et al., 2003, p 569). Having a good leader nowadays is considered to be one of most organizaions goals, to the best of * Corresponding author.

E-mail address: jarrah@aou.edu.kw (J. AlMansour) 
our knowledge, identifying the leadership styles of women in the public sector in Kuwait has largely been overlooked in previous literature. Therefore, this study represents a humble contribution to the field. This study is beneficial to the managers in the public sector, because many problems arise only from the leader's attitude displayed to his/her employees.

The study therefore aims at achieving the following two objectives:

- To identify the different leadership styles of women in the public sector in Kuwait, and

- To examine if the identified leadership styles of women vary in terms of the demographic characteristics of their subordinates.

Extensive research has explored leadership from various perspectives. The early studies of leadership have made a distinction between the characteristics of the leader and the characteristics of the followers. Then, researchers have begun to discuss the effect of the situation on the various leaders' skills and behaviors (Mendez-Morse, 1992). Research has also distinguished between effective and non-effective leaders and explored the leaders' behaviors and skills (Fiedler, 1967). Moreover, researchers (e.g., Mendez-Morse, 1992; Blumberg \& Greenfield, 1986) have used the contingency theory to scrutinize the relationship between personalized features, circumstantial changes, and effectiveness of the leader. Furthermore, researchers have explored the interaction between leaders and their followers concluding that the leaders' traits, skills and behaviors are combined and applied to form what so called the leadership style (Sonfield \& Lussier, 2004). The gender of the leader plays an important role as they differ in the way they act, communicate and influence their followers. The majority of women are making their path to senior management using the skills, and the attitudes they have (Patel, 2013). In this regard, Alzougool et al. (2015) found that there were significant differences between women and men in displaying the transformational and the passive avoidant leadership styles. Female managers frequently displayed the transformational leadership style more than male managers. For the passive avoidant leadership style, male manager fairly often displayed it while female managers displayed it once in a while. Merchant (2012) found that female leaders could provide a closer bond with their followers compared with the male leaders. Ely and Rhode (2010) also found that females do business more effectively than males. Moreover, Eagly et al. (2003) examined research (A meta-analysis of 45 studies) that compared women and men on transformational, transactional, and laissez-faire leadership styles. The study found that female leaders were more transformational than male leaders and also engaged in more of the contingent reward behaviors that are a component of transactional leadership. Male leaders were generally more likely to manifest the other aspects of transactional leadership (active and passive management by exception) and laissez-faire leadership. With respect to the GCC region, there have been a number of researches that recognized differences in terms of women leadership such as Qatar (Golkowska, 2017), Saudi Arabia (Kattan et al., 2016), Kuwait (AlSalem \& Speece, 2017), UAE (Kemp et al., 2015, Kemp et al. 2013), and Oman (Belwal et al., 2014). In this regards, Abdalla and Al-Homoud (2001) identified six important contributing dimensions for Kuwaiti and Qatari outstanding leadership behavior including diplomatic behavior, visionary behavior, integrity behavior, inspirational behavior, performance-oriented behavior, and administratively competent behavior. Hodges (2017) found that several factors affecting the women leadership styles in the Saudi Context, these include, social factors, religious factors, cultural factors, and factors related to the organizational practices. However, even with these constrains, their study provided support for the desire and readiness for change among women leadership in KSA. However, there is still a dearth of recent research looking into the women leadership in terms of leadership styles, consequent characteristics, values, and needed actions in the Middle East countries (Javidan \& Carl, 2004).

\section{Research Model}

A numerous number of theories have addressed different leadership styles. Khan et al. (2016) conducted a literature review on the leadership theories and styles. Main theories that emerged during 20th century include: the Great Man theory, Trait theory, Process leadership theory, Style and Behavioral theory, Transformational, Transactional and Laissez Faire leadership theory. However, the most prominent theory that has been studied and discussed in the literature is Bass's model of leadership styles. This model contains nine different styles that can be classified under three main styles namely transformational, transactional and laissez faire styles (which were investigated in this study). These styles represent the styles that might be displayed by any given manager. Definitions of these three main Styles and their related styles are shown in Table 1 (Adopted from Eagly et al. 2003, p 570).

\section{Table 1}

Definitions of Transformational, Transactional, and Laissez-Faire Leadership Styles (Adopted from Eagly et al. 2003, p 570)

\begin{tabular}{ll}
\hline Leadership style & Description of leadership style \\
\hline Transformational & \\
Idealized Influence (attribute) & Demonstrates qualities that motivate respect and pride from association with him/her \\
Idealized Influence (behavior) & Communicates values, purpose, and importance of organization's mission \\
$\begin{array}{l}\text { Inspirational Motivation } \\
\text { Intellectual Stimulation }\end{array}$ & Exhibits optimism and excitement about goals and future states \\
Individualized Consideration & Examines new perspectives for solving problems and completing tasks \\
Transactional & Focuses on development and mentoring of followers and attends to their individual needs \\
Contingent Reward & Provides rewards for satisfactory performance by followers \\
Management by Exception (active) & Attends to followers' mistakes and failures to meet standards \\
Management by Exception (passive) & Waits until problems become severe before attending to them and intervening \\
Laissez-Faire & Exhibits frequent absence and lack of involvement during critical junctures \\
\hline
\end{tabular}


In the transformational leadership style, the followers normally would carry trust, admiration, loyalty and respect towards the leader. Therefore, the followers become motivated to exceed what they were originally expected to perform (Katz and Kahn, 1978). The leaders who have this leadership style motivate their followers to think critically and seek new ways to approach their jobs correctly, resulting in intellectual stimulation (Bassetal, 1994). Alzougool et al. (2015) found that the most dominant style among female managers in Jordan was the transformational leadership style. Chao (2017) found a common use of the transformational leadership style by the Chinese female leaders. Gobaw (2017) found top-level leaders tend to have more of the characteristic types of transformational leadership. Cuadros et al. (2018) found the elements of Transformational Leadership are predominant over the other types of Leadership. In the transactional leadership style, the leader aim is both to ensure that all followers are clearly understand how to achieve the goals of the organization, and to encourage and motivate the followers to fulfill the desired goals (House and Aditya, 1997). In this regard, Sabri (2007) found that managers showed more inclination towards transactional than transformational leadership style. Moreover, Yaseen (2010) found that Arab-male leaders frequently behaved the transactional style and the Laissez-faire rather than females' leaders do. The third leadership style is the laissez-faire; the strategy of leader here is to let the followers to work on their own without any interference as the leaders believe in the freedom of the choice for their followers. The basis for this style of leadership has two aspects: (i) a strong belief about the followers' knowledge of their jobs and their tasks they are expected to best achieve, and (ii) the leaders may be in political, election-based positions where they may not wish to utilize their power or control for fear of not being reelected again (Goodnight 2004). Therefore, the leaders provide minimal information and resources to their followers. There is virtually no participation, involvement, or communication within the workforce, but on the other hand, understanding the job requirements, policies, and procedures are generally left to be exchanged from employee to employee (Wood, 2009).

\section{Methods}

The main method of data collection was a questionnaire which was distributed to a sample of employees in the public sector in Kuwait. The target population for this study was all levels of employees as long as they have a female leader who leads and manages them. The study adopted the "Multifactor Leadership Questioner MLQ (5x-short form)", which was developed by Bass and Avolio (2004); an instrument that was extensively researched, statically reliable and tested on various employees and industries. Some modifications were added to suit the context of this study and it was translated to the Arabic language. Section A in the survey includes the employees' profile such as gender, age, marital status, educational level and job title. Section B includes the items used to measure the nine leadership styles i.e.: idealized influence (attributed), idealized influence (behavior), inspirational motivation, intellectual stimulation, individualized consideration, contingent reward, managementby-exception (active), management-by-exception (passive), and laissez-faire leadership. A five-point response scale (not at all, once in a while, sometimes, fairly often, frequently if not always) was used.

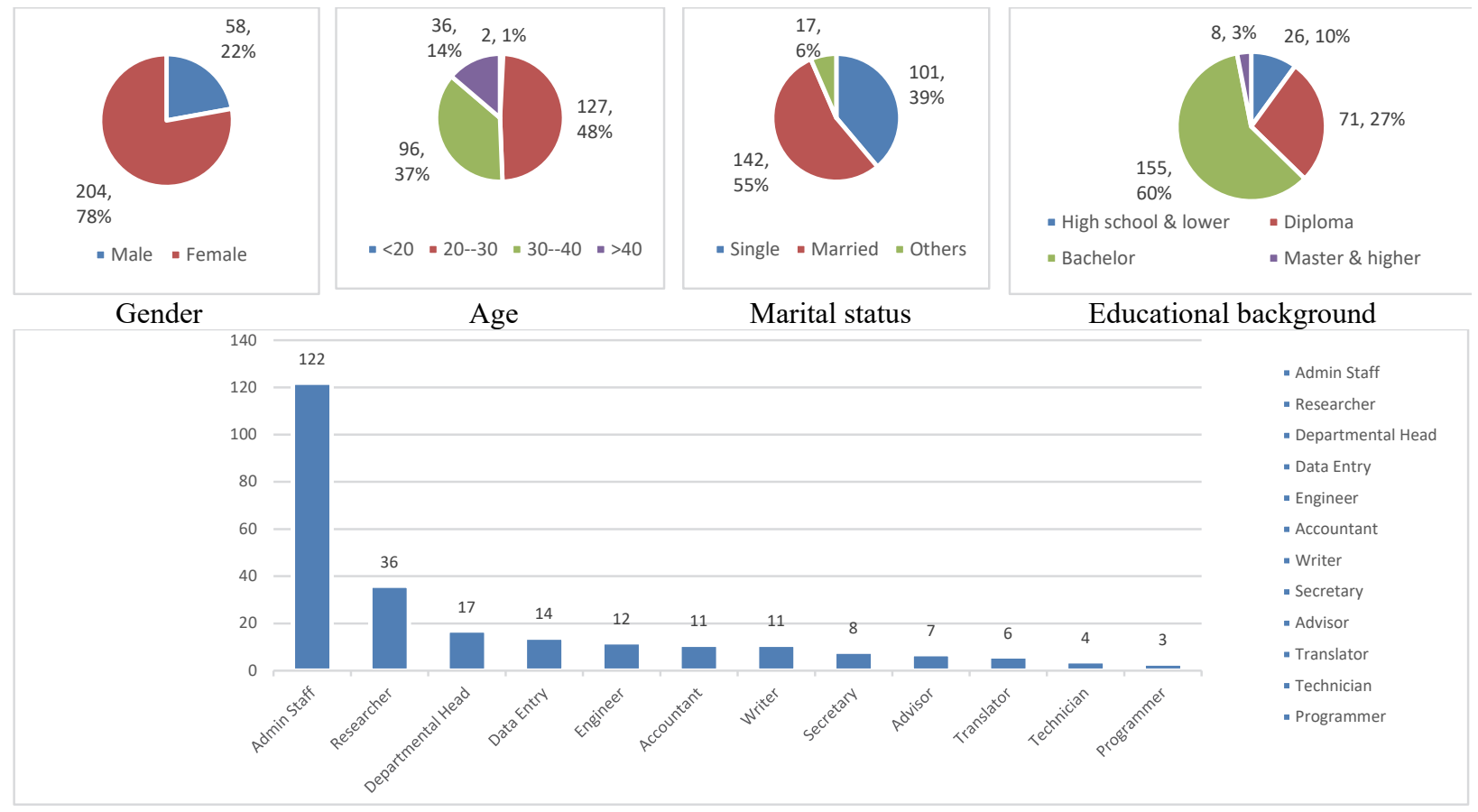

Job title

Fig. 1. Personal characteristics of the participants

The survey was distributed through a personal visit by the second and third authors. The participants were explained the purposes of the study and asked to complete the surveys. The instructions for completing the questionnaire were given on the 
cover page to avoid any misunderstanding about the leadership styles issue. In all, 500 surveys were administered to employees in the public sector in Kuwait. 282 surveys were completed by the participants. Of these, 19 surveys were ignored because of missing data and the employees were non Kuwaitis. Therefore, only 263 surveys were usable for this study and included in the analysis. A summary of the demographic characteristics of the respondents is presented in Fig. 1. As shown in the figure, the majority of the employees were females (77.9\%). While, approximately half of the employees belong to the age group 21-30 years (48.7\%) and more than third of them belong to the age group 31-40 years (36.7\%). In addition, more than half of the employees were married (54.7\%) and approximately two thirds of the employees have bachelor degree (59.6\%). Approximately half of the employees have the job title of administrative staff (48.6\%). All participants have female managers.

\subsection{Data Analysis and Findings}

This study aimed to identify the different leadership styles of women in Kuwait and examine if the identified leadership styles of women vary in terms of the demographic characteristics of participated employees. The data obtained from the study were analyzed through various techniques in SPSS 19.0 program. Data analysis involves three processes. First, the descriptive statistics (mean and standard deviation) were used to identify the current state of leadership styles. Second, confirmatory factor analysis and reliability (by computing the Cronbach's alpha) of the measurement model were evaluated. Finally, t-test was used to find out if the identified leadership styles of women vary in terms of the demographic characteristics of participated employees. Table 2 illustrates the mean $(M)$ and standard deviations $(S D)$ of the current state of women leadership styles in the public sector in Kuwait; the following scale is used to facilitate reporting the results:

- The leadership style was frequently if not always displayed by female managers: Calculated mean $(M \geq 3.6)$.

- The leadership style was fairly often displayed by female managers: Calculate mean $(2.4 \geq M<3.6)$.

- The leadership style was occasionally displayed by female managers: Calculated mean $(M<2.4)$.

As shown in the table, employees perceived that four leadership styles were frequently if not always displayed by their female managers namely: inspirational motivation (mean=3.79), Idealized influence (attribute) (mean=3.74), Contingent reward $($ mean $=3.73)$, and Intellectual stimulation (mean=3.61). Three leadership styles were fairly often displayed by their female managers namely: Management by exception (active) (mean=3.54), Idealized influence (behavior) (mean=3.44), and Individualized consideration (mean=3.38). While two leadership styles were displayed occasionally by their female managers namely: Management by exception (passive) (mean=2.36), and Laissez-faire (mean=2.32).

Table 2

The mean scores of women leadership styles $(\mathrm{N}=263)$

\begin{tabular}{|c|c|c|c|}
\hline Leadership styles & $\mathbf{N}$ & Mean & SD \\
\hline Inspirational Motivation & 245 & 3.79 & 1.05 \\
\hline Idealized Influence (attribute) & 244 & 3.74 & 0.98 \\
\hline Contingent Reward & 246 & 3.73 & 0.90 \\
\hline Intellectual Stimulation & 245 & 3.61 & 0.95 \\
\hline Management by Exception (active) & 245 & 3.54 & 0.87 \\
\hline Idealized Influence (behavior) & 240 & 3.44 & 0.88 \\
\hline Individualized Consideration & 242 & 3.38 & 0.92 \\
\hline Management by Exception (passive) & 230 & 2.36 & 0.97 \\
\hline Laissez-faire & 247 & 2.32 & 0.91 \\
\hline
\end{tabular}

In terms of factor analysis and as presented in Table 3, the nine leadership styles formed two conceptually sound factors. The first factor has seven leadership styles and it was interpreted as the transformational leadership style, and the second factor has two leadership styles and it was interpreted as the passive-avoidant leadership style. All the factor loadings were greater than 0.7. The Cronbach's alpha for the first and second factors was 0.94 and 0.82 respectively. Construct reliability is achieved if the alpha values are above the acceptable value of 0.7 (Nunnally, 1978).

Table 3

The results of factor analysis

\begin{tabular}{|c|c|c|}
\hline Leadership styles/factors & Transformational & Passive-avoidant \\
\hline Inspirational Motivation & .907 & \\
\hline Intellectual Stimulation & .885 & \\
\hline Contingent Reward & .881 & \\
\hline Idealized Influence (attribute) & .861 & \\
\hline Individualized Consideration & .856 & \\
\hline Idealized Influence (behavior) & .837 & \\
\hline Management by Exception (active) & .767 & \\
\hline Management by Exception (passive) & & .923 \\
\hline Laissez-faire & & .917 \\
\hline
\end{tabular}

Based on the findings of factor analysis, the mean of the two factors (the main leadership styles) were calculated. As shown in Table 4, employees perceived that the transformational style was frequently if not always (mean=3.63) displayed by their female managers, while the passive-avoidant style displayed occasionally (mean=2.34) by their female managers in the public 
sector in Kuwait. Therefore, the dominant leadership style among female managers in the public sector in Kuwait is the transformational style.

Table 4

The mean scores of the three main leadership styles of women (Based on Factor analysis)

\begin{tabular}{lccc}
\multicolumn{1}{c}{ Main leadership styles } & N & Mean & SD \\
\hline Transformational & 193 & 3.63 & .79 \\
Passive-avoidant & 219 & 2.34 & .87 \\
\hline
\end{tabular}

The t-test was also conducted to look for significant differences in the two leadership styles of women identified in the study (i.e. transformational and passive-avoidant) in terms of five background variables of the participated employees: gender, age group, marital status, educational level, and job title. Results are summarized in Table 5. When the mean score of transformational leadership style was compared across the two different categories of each of the five dichotomous background variables, there were strong significant differences in this leadership style's mean scores for the educational level $(\mathrm{t}=2.976, \mathrm{df}=189$, $\mathrm{p}=0.003)$ and job title of employees $(\mathrm{t}=4.216, \mathrm{df}=184, \mathrm{p}=0.000)$. Employees who have diploma and lower $(\mathrm{mean}=3.87)$ and work as administrative staff (mean=3.83) perceived that their female managers frequently if not always displayed transformational leadership style while employees who have bachelor and higher degrees (mean=3.52) and work as non-administrative staff (mean=3.36) perceived that their female managers fairly often displayed this leadership style. No significant differences in the transformational leadership style can be related to the gender, age group, and marital status of participated employees. On the other hand, no significant differences in the passive-avoidant leadership style can be related to the five background variables of the participated employees.

Table 5

Comparison of means \& t-values of the identified leadership styles in terms of five background variables of the participated employees

\begin{tabular}{|c|c|c|c|c|c|c|}
\hline Transformational leadership style & $\mathbf{N}$ & Mean & SD & $\mathbf{T}$ & df & $\mathbf{P}$ \\
\hline Male & 40 & 3.73 & .841 & \multirow[t]{2}{*}{1.004} & \multirow[t]{2}{*}{190} & \multirow[t]{2}{*}{.317} \\
\hline Female & 152 & 3.59 & .766 & & & \\
\hline $30 \&$ below & 95 & 3.69 & .798 & \multirow[t]{2}{*}{1.124} & \multirow[t]{2}{*}{191} & \multirow[t]{2}{*}{.262} \\
\hline $31 \&$ above & 98 & 3.57 & .770 & & & \\
\hline Single & 75 & 3.65 & .714 & \multirow[t]{2}{*}{.595} & \multirow[t]{2}{*}{174} & \multirow[t]{2}{*}{.553} \\
\hline Married & 101 & 3.59 & .796 & & & \\
\hline Diploma \& lower & 66 & 3.87 & .799 & \multirow[t]{2}{*}{2.976} & \multirow[t]{2}{*}{189} & \multirow[t]{2}{*}{$.003 *$} \\
\hline Bachelor \& higher & 125 & 3.52 & .753 & & & \\
\hline Admin. Staff & 107 & 3.83 & .750 & \multirow[t]{2}{*}{4.216} & \multirow[t]{2}{*}{184} & \multirow[t]{2}{*}{$.000^{*}$} \\
\hline Non-Admin. Staff & 79 & 3.36 & .758 & & & \\
\hline Passive-avoidant leadership style & $\mathbf{N}$ & Mean & SD & $\mathbf{T}$ & df & $\mathbf{P}$ \\
\hline Male & 46 & 2.29 & .950 & \multirow{2}{*}{$-.372-$} & \multirow[t]{2}{*}{216} & \multirow[t]{2}{*}{.711} \\
\hline Female & 172 & 2.34 & .826 & & & \\
\hline $30 \&$ below & 107 & 2.29 & .949 & \multirow{2}{*}{$-.883-$} & \multirow[t]{2}{*}{215} & \multirow[t]{2}{*}{.378} \\
\hline $31 \&$ above & 110 & 2.39 & .772 & & & \\
\hline Single & 85 & 2.23 & .769 & \multirow[t]{2}{*}{$-1.284-$} & \multirow[t]{2}{*}{198} & \multirow[t]{2}{*}{.201} \\
\hline Married & 115 & 2.38 & .855 & & & \\
\hline Diploma \& lower & 77 & 2.31 & .918 & \multirow[t]{2}{*}{$-.152-$} & \multirow[t]{2}{*}{214} & \multirow[t]{2}{*}{.880} \\
\hline Bachelor \& higher & 139 & 2.33 & .839 & & & \\
\hline Admin. Staff & 118 & 2.33 & .970 & \multirow[t]{2}{*}{.078} & \multirow[t]{2}{*}{209} & \multirow[t]{2}{*}{.938} \\
\hline Non-Admin. Staff & 93 & 2.33 & .734 & & & \\
\hline
\end{tabular}

$$
* \mathrm{p}<0.05
$$

\section{Discussion}

According to the findings of the study, women in the public sector in Kuwait frequently if not always displayed the following leadership styles: inspirational motivation, Idealized influence (attribute), Contingent reward, and Intellectual stimulation. This means that women leaders motivate, encourage their subordinates through highlighting the importance of the individual's input to achieve desired goals. On the other hand, women fairly often displayed three leadership styles: management by exception (active), Idealized influence (behavior), and Individualized consideration. While women occasionally displayed two leadership styles: management by exception (passive), and Laissez-faire which imply that women leaders believes in the freedom of their employees in making decisions.

The most dominant style among female managers in Kuwait was the transformational leadership style. This indicates that women leaders possess integrity, set a good example and excel in achieving communication within all levels. They also expect the best from their followers, and inspire them to elevate the interest of the team over their own. This result is consistent with previous studies which found that the transformational leadership style is highly displayed by women. 
The study found that the employees' educational level and job title of impacted on how these employees perceive the transformational leadership style of their female managers in the public sector in Kuwait. Employees who have diploma and lower and work as administrative staff perceived that their female managers frequently if not always displayed transformational leadership style while employees who have bachelor and higher degrees and work as non-administrative staff perceived that their female managers fairly often displayed this leadership style. However, the study found that the employees' gender, age group, and marital status did not impact on how these employees perceive the transformational leadership style of their female managers. For the passive avoidant leadership style, employees perceived that their female managers occasionally displayed this leadership style regardless of their gender, age group, marital status, educational level and job title.

\section{Conclusion and Recommendations}

Much has been written about different leadership styles in the world in general and in Kuwait in particular. However, to the best of our knowledge, little has been devoted to focus on women's leadership styles in particular especially in Kuwait. The aim of this study was twofold: (i) to identify the different leadership styles of women in the public sector in Kuwait, and (ii) to examine if the identified leadership styles of women vary in terms of the demographic characteristics of their subordinates. A quantitative approach (questionnaire with 263 employees) was conducted in order to achieve the study objectives. The results of the study showed that women in public sector in Kuwait frequently displayed various leadership styles as perceived by their followers such as inspirational motivation, idealized influence (attribute) styles. Some other styles were displayed fairly often such as management by exception (active), idealized influence (behavior). Moreover, the dominated leadership styles that displayed frequently by women was the transformational style. Furthermore, the study found that the transformational leadership style of women varied in terms of the educational level and job title of their followers. The transformational leadership style of women was displayed frequently as perceived by employees who have diploma and lower and work as administrative staff while it was displayed fairly often as perceived by employees who have bachelor and higher degrees and work as non-administrative staff.

In light of the above results, the following recommendations may improve the effectiveness of women leadership in the public sector:

First, this study is beneficial to the leaders in public sector, because many problems arise only from the leader's attitude displayed to his/her employees.

Second, one of the main findings of the study had showed that female leaders in the public sector in Kuwait displayed several leadership styles. Therefore, this study recommend that the public sector may demonstrate the adaptive leadership style accordingly taking into consideration the rapidly changing work nature, culture, code of conduct, and ethics. The results of the study could help to shape how female managers interact with their subordinates in making a suitable work environment. Transformational leadership style could create the most motivated employees who can make substantial changes to the public sector. Transformational leadership also concerns a focused attempt to produce awareness in the organization while seeking to increase the confidence of the employees (Caillier, 2014).

Third, it has been concluded that female leaders have displayed the transformational leadership style more frequently than the other leadership styles. Therefore, female leaders who adopt the transformational leadership style may maintain it in the working place and train other female leaders as it had seen to be more efficient and effective. Transformational leadership had a positive impact on followers. Transformational leadership involves motivating followers to commit to shared targets, challenging followers to be innovative problem solvers, and developing followers' leadership capacity through coaching, mentoring, and the provision of challenge and support (Bass and Avolio, 2004). When an employee perceives support from organizational leaders, his or her individual sense of accomplishment and contributions to the organization improves (Hamid and D'Silva, 2014). In this regard, workers who received organizational support were effectively inclined to work hard (Hamid and D'Silva, 2014).

Finally, the findings may become a source of information for the academic debate on how transformational leadership is relevant to women leadership styles in public sector in Kuwait.

\section{References}

Abdalla, I., \& Al-Homoud, M. (2001). Exploring the implicit leadership theory in the Arabian Gulf states. Applied Psychology: An International Review, 50(4), 506-31.

Al-Salem, A., \& Speece, M. (2017). Women in leadership in Kuwait: a research agenda. Gender in Management: An International Journal, 32(2), 141-162.

Alzougool, B., Elbargathi, Kh., Habib, H., Khalaf, B., \& Al-Qutub, D. (2015). Women's leadership styles in private sector in Jordan. International Journal of Innovation, Management and Technology, 6(3), 166-173.

Alzuabi, A. Z. (2016). Sociopolitical participation of Kuwaiti women in the development process: Current state and challenges ahead. Journal of Social Service Research, 42(5), 689-702, DOI: 10.1080/01488376.2016.1212775.

Bass, B., \& Avolio, B. (2004). Multifactor leadership questionnaire. $3^{\text {rd }}$ ed., Redwood City, CA: Mind Garden.

Belwal, S., Belwal, R., \& Saidi, F. (2014). Characteristics, motivations, and challenges of women entrepreneurs in Oman's Al-Dhahira region. Journal of Middle East Women's Studies, 10(2), 135-151. 
Blumberg, A., \& Greenfield, W. (1986). The effective principal: Perspectives on school leadership. Publication Sales, Allyn and Bacon, Longwood Division, 7 Wells Avenue, Newton, MA 02159 (Order No. H87406; \$29.95).

Bolden, R. (2004). What is leadership? United Kingdom: Leadership South West.

Caillier, J. G. (2014). Toward a better understanding of the relationship between transformational leadership, public service motivation, mission valence, and employee performance: A preliminary study. Public Personnel Management, 43, 218239.

Chao, C. (2017). The Chinese female leadership styles from the perspectives of trait and transformational theories. China Media Research, 13(1), 63-73.

Cuadros, M. P., Cáceres R. M., \& Lucena, F. J (2018). Analysis of leadership styles developed by teachers and administrators in technical-technological programs: the case of the Cooperative University of Colombia. International Journal of Leadership in Education, 21(1), 1360-3124.

Eagly, A., Johannesen-Schmidt, M., \& Engen, M. (2003). Transformational, transactional, and Laissez-Faire leadership Styles: A meta-analysis comparing women and men. Psychological Bulletin, 129(4), 569-591.

Ely, R., \& Rhode, D. (2010). Women and Leadership: Defining the Challenges. In Handbook of Leadership Theory and Practice, Nohria, N. and Khurana, R. Ed., Boston, MA: Harvard Business Publishing, pp. 377-410.

Fiedler, F. (1967) A theory of leadership effectiveness, New York: McGraw-Hill.

Gobaw, M. K. (2017). Women's role and their styles of leadership. International Journal of Educational Administration and Policy Studies, 9(3), 28-34.

Golkowska, K. (2017) Qatari women navigating gendered space. Social Sciences, 6(4), 123.

Goodnight, R. (2004) Laissez-Faire Leadership: Encyclopedia of Leadership, SAGE Publications.

Hamid, J. A., \& D'Silva, J. L. (2014). The effect of leadership attributes and motivation to lead on preferred job characteristics (job attributes): Case study of undergraduates in Malaysian universities. International Journal of Business and Management, 9, 230-238. doi:10.5539/ijbm.v9n12p230

Hodges, J. (2017). Cracking the walls of leadership: women in Saudi Arabia. Gender in management: An international journal, 32(1), 34-46.

Holmes, F. (2014). The Importance of Women Leaders: From Margaret Thatcher to Sheryl Sandberg to Park Geun-hye, U.S. Global Investors.

House, R., \& Aditya, R. (1997). The social scientific study of leadership: Quo Vadis?. Journal of Management, 23(3), 409473.

Javidan, M., \& Carl, D. (2004). East meets west: a cross-cultural comparison of charismatic leadership among Canadian and Iranian executives. Journal of Management Studies, 41(4), 665-92.

Kattan, M., de Pablos Heredero, C., Botella, J., \& Margalina, V. (2016) Factors of successful women leadership in Saudi Arabia. Asian Social Science, 12(5), 94-107.

Katz, D., \& Kahn, R. (1978) The social psychology of organizations. New York: Wiley, 1978.

Kemp, L., Madsen, S., \& El-Saidi, M. (2013) The current state of female leadership in the United Arab Emirates. Journal of Global Responsibility, 4(1), 99-112.

Kemp, L., Madsen, S., \& Davis, J. (2015) Women in business leadership: A comparative study of countries in the Gulf Arab states. International Journal of Cross Cultural Management, 15(2), 215-233.

Khan, Z. A, Nawaz, A., \& Khan, I. (2016). Leadership theories and styles: A literature review. Journal of Resources Development and Management, 16, 1-7.

Mendez-Morse, S. (1992). Leadership Characteristics That Facilitate School Change, Austin: Texas/USA, Southwest Educational Development Laboratory, 211 East 7th Street.

Merchant, K. (2012). How Men And Women Differ: Gender Differences in Communication Styles, Influence Tactics, and Leadership Styles. CMC Senior Theses, Paper 513.

Nunnally, J. (1978). Psychometric theory. $2^{\text {nd }}$ ed. New York: McGraw-Hill.

Patel, G. (2013) Gender Differences in Leadership Styles and the Impact Within Corporate Boards, United Kingdom.

Rohmann, A., \& Rowold, J. (2009) Gender and leadership style: A field study in different organizational contexts in Germany. Equal Opportunities International, 28(7): 545 - 560.

Sabri, H. (2007) Jordanian managers' leadership styles in comparison with the International Air Transport Association (IATA) and prospects for knowledge management in Jordan. International Journal of Commerce and Management, 17(1/2), 56$72,2007$.

Schmidt, S., Shelley, J., Bardes, B., \& Ford, L. (2014). American government and politics today. Boston, MA: Wadsworth, Cengage Learning.

Sonfield, M., \& Lussier, R. (2004) First-, second-, and third-generation family firms: A comparison. Family Business Review, 17(3), 189-202.

Wood, J. (2009) Communication in Our Lives. $5^{\text {th }}$ ed. Boston, USA: Learning.

Yaseen, Z. (2010) Leadership styles of men and women in the Arab world. Education, Business and Society: Contemporary Middle Eastern Issues, 3(1), 63-70. 
(C) 2020 by the authors; licensee Growing Science, Canada. This is an open access article distributed under the terms and conditions of the Creative Commons Attribution (CC-BY) license (http://creativecommons.org/licenses/by/4.0/). 